\title{
BRF2 Gene
}

National Cancer Institute

\section{Source}

National Cancer Institute. BRF2 Gene. NCI Thesaurus. Code C20672.

This gene plays a role in transcriptional initiation and has been purported to play an oncogenic role in breast cancer development. 